\title{
A population based study on under nutrition and certain associated risk factors among children less than five years in a rural area
}

\author{
Samya V., Meriton Stanly A.*
}

\begin{abstract}
Department of Community Medicine, Sri Ramachandra Medical College \& Research Institute, Sri Ramachandra University, Porur, Chennai, India
\end{abstract}

Received: 28 September 2015

Revised: 03 October 2015

Accepted: 20 October 2015

\author{
*Correspondence: \\ Dr. Meriton Stanly, \\ E-mail: dramstanly@yahoo.co.in
}

Copyright: ( $)$ the author(s), publisher and licensee Medip Academy. This is an open-access article distributed under the terms of the Creative Commons Attribution Non-Commercial License, which permits unrestricted non-commercial use, distribution, and reproduction in any medium, provided the original work is properly cited.

\begin{abstract}
Background: Child health indicators in developing countries show that there is still a long way to go to improve child health. Majority of the causes of mortality and morbidity in this 'under 5' age group are preventable through existing interventions. This study aims to identify the prevalence of under nutrition and the associated risk factors to improve the health status of children and the quality of life in rural India. The objective of the study was to estimate the prevalence of under-nutrition among children less than 5 years in a rural area and to find out the association between under nutrition and certain socio-economic, demographic, and environmental factors among children less than 5 years in a rural area.

Methods: Children less than 5 years of age were listed from the family register in the sub-centres and were selected by simple random sampling method. Limit of accuracy was taken as $12 \%$ of prevalence and Z (1- $\alpha / 2)$ value of 1.96 . $5 \%$ of the sample was added to take care of non-response and the final sample size was calculated as 370 .

Results: Based on WHO classification 2006 (weight for age), 46\% of the children were normally nourished. Among the malnourished children, $37.6 \%$ were mildly under-nourished, $12.2 \%$ were moderately under-nourished and the remaining $4.3 \%$ were severely under-nourished. Children born with a low birth weight, children who were not exclusively breastfed, birth spacing of $<18$ months, children living in overcrowded houses were at a significantly higher risk of being under-nourished. Children who had more than 3 episodes of ARI in the past one year were also at a risk of under nutrition.

Conclusions: The high Prevalence of under-nutrition could be due to low birth weight, spacing of pregnancy less than 18 months, non -exclusive breast feeding, delayed weaning, recurrent respiratory infections and poor housing conditions. Better maternal care, exclusive breastfeeding, proper weaning and improvement in standard of living in rural area will reduce the problem of under nutrition among children less than 5 years.
\end{abstract}

Keywords: Under Nutrition, Children less than 5 years, Prevalence

\section{INTRODUCTION}

Children less than 5 years of age are most affected by various common morbidities, some of which lead also to mortality in this vulnerable population. Child health indicators in developing countries show that there is still a long way to go to improve child health. Even though the Infant Mortality Rate has declined considerably, the differentials of rural and urban is still high; the value stands at 51 per 1000 in rural compared to 31 per 1000 in the urban. Though the urban Under 5 Mortality Rate has already achieved the Millenium Development Goals target of 42 by 2015, the rural Under 5 Mortality Rate is still as high as $61 .^{1}$ Majority of the causes of mortality 
and morbidity in this 'under 5' age group are preventable through existing interventions. Protein energy malnutrition is one of the major health and nutritional problem in India. It is not only an important cause of childhood mortality and morbidity but also leads to permanent impairment of physical, and possibly mental growth of those who survive. ${ }^{2}$ The well-being of children is the best global indicator for the growth of the nation. Growth assessment not only provides nutritional and health status of children but it is also an indirect measurement of the quality of life of the entire population. This study aims to identify the prevalence of under nutrition in a rural area in Tamil Nadu, India and the associated risk factors which if properly addressed will help to improve in the long run, the health status of children and the quality of life in rural India.

The objective of the present study was to estimate the prevalence of under-nutrition among children less than 5 years in a rural area and to find out the association between under nutrition and certain socio-economic, demographic, and environmental factors among children less than 5 years in a rural area.

\section{METHODS}

The study was a population based cross sectional study done at the Primary Health Centre area of Nemam in Poonamallee block of Thiruvallur district, Tamil Nadu, India. The study population consisted of all children under 5 years of age residing in the PHC area. Totally there were 2373 children, among which 841 belonged to Nemam sub centre, 541 belonged to Kuthambakkam and 991 from Pappanchathram. Data collection was done from November 2012 to January 2013. Sample size was calculated considering the prevalence of under nutrition as $43 \%$ based on NFHS 3 data. Limit of accuracy was taken as $12 \%$ of prevalence and $Z(1-\alpha / 2)$ value of 1.96 . $5 \%$ of the sample was added to take care of non-response and the final sample size was calculated as 370 . Children less than 5 years of age were listed out from the family register in the sub-centres and were selected by simple random sampling method. Data entry and analysis were done using SPSS 15.0 for windows software. Prevalence of Malnutrition and $95 \%$ Confidence Interval were calculated. Odds Ratio, chi square test and $\mathrm{p}$ values were estimated to find out the associated risk factors for malnutrition.

\section{RESULTS}

Among the 370 children, 181 (48.9\%) were females, and $189(51.1 \%)$ were males with a mean age of 32.38 (SD 15.58). Age and sex distribution is in table $1.70 .8 \%$ of the children belonged to a nuclear family; $1.9 \%$ from extended nuclear family; and $27.3 \%$ belonged to joint family. The mean family size was 1.87 .The mean birth weight of the study children were $2708.2 \mathrm{gm}$ (SD 514.7) ranging from a minimum of $1150 \mathrm{gm}$ to $5000 \mathrm{gm}$. The proportion of low birth weight was $14.3 \%$ (n53). $2.2 \%$ of the children were twin births. Details of birth spacing were collected from 188 respondents where the children were of birth order 2 or more. Among them the birth spacing was more than 2 years for most of the children (58\%) and it was 18 to 24 months for $22.9 \%$ children and less than 18 months for $19.1 \%$ children.

Table 1: Age and sex distribution.

\begin{tabular}{|lll|l|}
\hline $\begin{array}{l}\text { Age of the } \\
\text { child (years) }\end{array}$ & $\begin{array}{l}\text { Male } \mathbf{N} \\
(\%)\end{array}$ & $\begin{array}{l}\text { Female } \mathbf{N} \\
(\%)\end{array}$ & $\begin{array}{l}\text { No of } \\
\text { children } \mathbf{n}\end{array}$ \\
\hline $0-1$ & $19(48.7)$ & $20(51.3)$ & 39 \\
\hline $1-2$ & $53(62.4)$ & $32(37.6)$ & 85 \\
\hline $2-3$ & $41(48.8)$ & $43(51.2)$ & 84 \\
\hline $3-4$ & $41(43.6)$ & $53(56.4)$ & 94 \\
\hline $4-5$ & $35(51.5)$ & $33(48.5)$ & 68 \\
\hline Total & $189(51.1 \%)$ & $181(48.9 \%)$ & 370 \\
\hline
\end{tabular}

Table 2: Distribution of nutritional status of selected children.

\begin{tabular}{|lllllllll|}
\hline $\begin{array}{l}\text { Age in } \\
\text { years }\end{array}$ & $\begin{array}{l}\text { Normal } \\
\text { Male N } \\
(\%)\end{array}$ & $\begin{array}{l}\text { Female N } \\
(\%)\end{array}$ & $\begin{array}{l}\text { Male N } \\
(\%)\end{array}$ & $\begin{array}{l}\text { Female N } \\
(\%)\end{array}$ & $\begin{array}{l}\text { Male N } \\
(\%)\end{array}$ & $\begin{array}{l}\text { Female N } \\
(\%)\end{array}$ & $\begin{array}{l}\text { Severe } \\
(\%)\end{array}$ & $\begin{array}{l}\text { Female N } \\
(\%)\end{array}$ \\
\hline $0-1$ & $10(50)$ & $10(50)$ & $5(38.5)$ & $8(61.5)$ & $0(0)$ & $0(0)$ & $4(66.7)$ & $2(33.3)$ \\
\hline $1-2$ & $33(62.3)$ & $20(37.7)$ & $17(65.4)$ & $9(34.6)$ & $2(50)$ & $2(50)$ & $1(50)$ & $1(50)$ \\
\hline $2-3$ & $15(42.9)$ & $20(57.1)$ & $17(48.6)$ & $18(51.4)$ & $2(100)$ & $0(0)$ & $7(58.3)$ & $5(41.7)$ \\
\hline $3-4$ & $14(37.8)$ & $23(62.2)$ & $17(43.6)$ & $22(56.4)$ & $4(57.1)$ & $3(42.9)$ & $6(54.5)$ & $5(45.5)$ \\
\hline $4-5$ & $15(60)$ & $10(40)$ & $12(46.2)$ & $14(53.8)$ & $2(66.7)$ & $1(33.3)$ & $6(42.9)$ & $8(57.1)$ \\
\hline \multirow{2}{*}{ Total } & $87(51.2)$ & $83(48.8)$ & $68(48.9)$ & $71(51.1)$ & $10(62.5)$ & $6(37.5)$ & $24(53.3)$ & $21(46.7)$ \\
\hline
\end{tabular}

The immunization status was obtained for children aged 1-2 years ( $n$ 113). $82.3 \%$ of the children were fully immunized and $17.7 \%$ children were partially immunized. For children aged 7 to 18 months (n 118) details about exclusive breast feeding were collected. $87.7 \%$ of the children were exclusively breastfed. $42.4 \%$ 
of the children lived in overcrowded houses. It was found that $43 \%$ of the selected children had more than 3 episodes of acute respiratory infections in the past 1 year.

\section{Details of under-nutrition}

Based on WHO classification 2006 (weight for age), 46\% of the children were normally nourished. Among the malnourished children, $37.6 \%$ were mildly undernourished, $12.2 \%$ were moderately under-nourished and the remaining $4.3 \%$ were severely under-nourished. Details of nutritional status based on weight for age is shown in table 2, and fig.1. Age and sex wise distribution of under nutrition is given in table 3. Based on the midarm circumference measured for children aged 1-5 years (n 336), 60.1\% of the children were having a mid-arm circumference of $>13.5 \mathrm{~cm}, 28.6 \%$ of the children has mild-moderate under-nutrition with a mid-arm circumference of $12.5-13.5 \mathrm{~cm}$ and the remaining $11.3 \%$ of the children were severely under-nourished.

Table 3: Age and sex wise distribution of under nutrition.

\begin{tabular}{|llll|}
\hline Particulars & $\mathbf{N}(\%)$ & Male $\mathbf{n}(\%)$ & Female $\mathbf{n}(\%)$ \\
\hline Age in years & & & \\
\hline $0-1$ & $19(48.7)$ & $9(47.4)$ & $10(52.6)$ \\
\hline $1-2$ & $32(37.6)$ & $20(62.5)$ & $12(37.5)$ \\
\hline $2-3$ & $49(58.3)$ & $26(53.1)$ & $23(46.9)$ \\
\hline $3-4$ & $57(60.6)$ & $27(47.4)$ & $30(52.6)$ \\
\hline $4-5$ & $43(63.2)$ & $20(46.5)$ & $23(53.5)$ \\
\hline Total & $200(54.1)$ & $102(48.6)$ & $98(51.4)$ \\
\hline
\end{tabular}

Table 4: Association of under nutrition and demographic, socioeconomic and environmental factors.

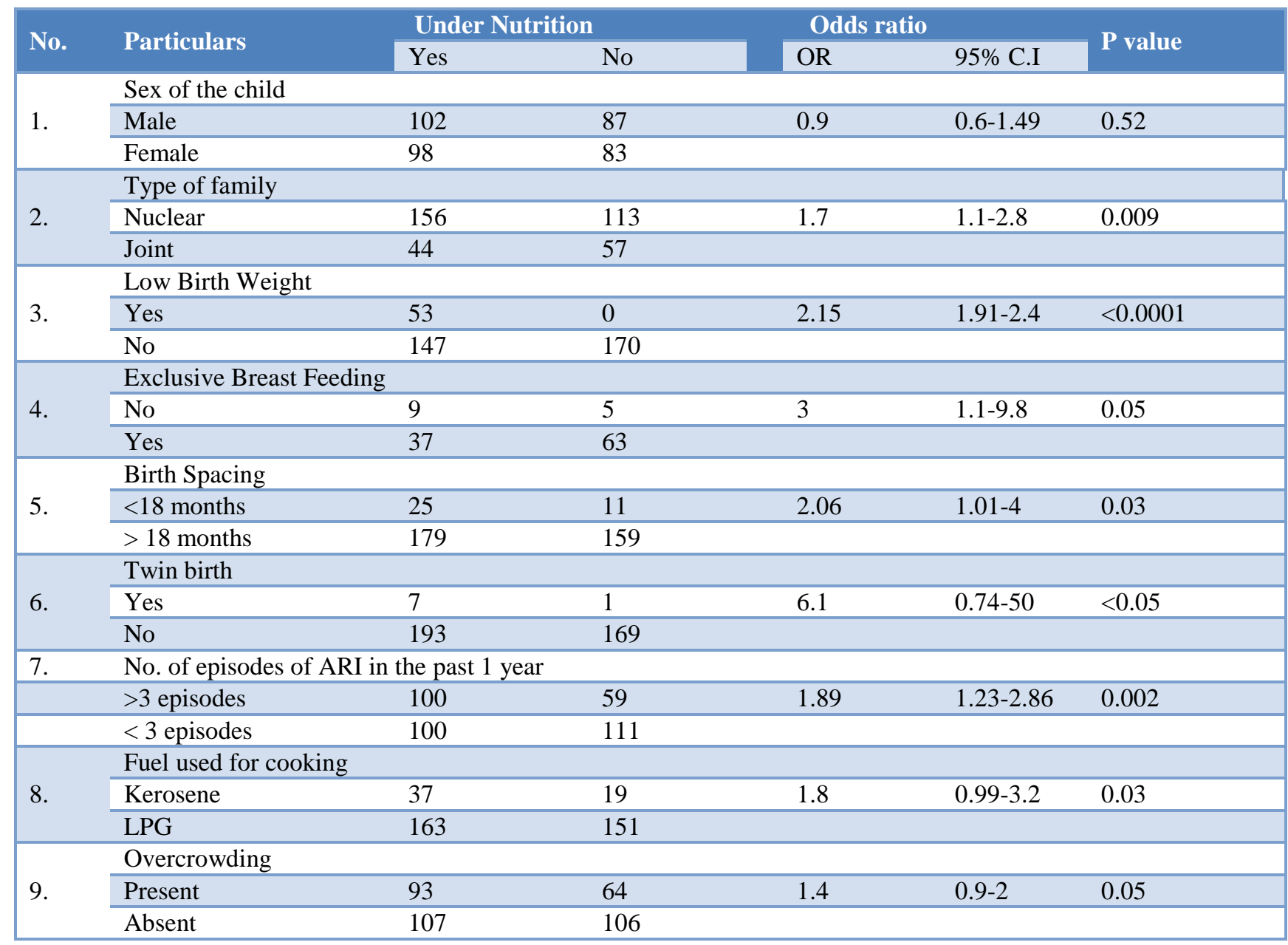

It was found that children living in nuclear families were significantly at a higher risk of under-nutrition $(\mathrm{p}<0.05$, OR 1.7). Children born with a low birth weight, children who were not exclusively breastfed, birth spacing of $<18$ months, children living in overcrowded houses, children living in houses where kerosene was used as cooking fuel were at a significantly higher risk of being undernourished. Children who had more than 3 episodes of 
ARI in the past one year were also at a risk of under nutrition Details of the associated factors with undernutrition is given in Table 4 .

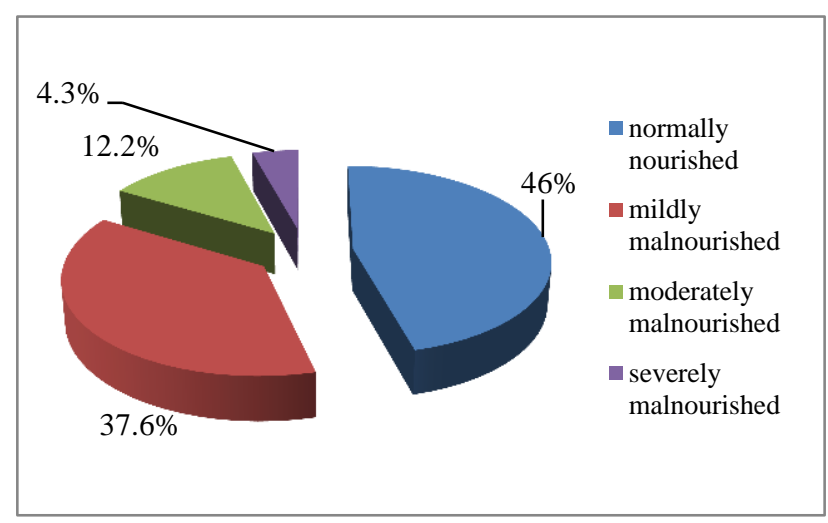

Figure 1: Nutritional status of selected children.

\section{DISCUSSION}

The overall prevalence of under nutrition was $54.1 \%$ which is quite high. In the study by Shreyaswi et al and Joshi et al, Shubhada et al and Stanly et al, the prevalence were $63.13 \%, 49.44 \%, 50.46 \%$ and $42.9 \%$ respectively; in NFHS 3 it was around $46 \%$ in Tamil Nadu. ${ }^{3-7}$ These differences could be due to the regional differences and the classification used for identifying under nutrition (IAP classification).

The prevalence of under nutrition was significantly higher in children living in nuclear families. Joshi et al also had similar findings. ${ }^{4}$ The other risk factors significantly associated with malnutrition included low birth weight, not exclusive breastfeeding, birth spacing less than 18 months. NFHS 3 also shows a similar association. In the study by Rutstein et al, decreased birth interval was significantly associated with undernutrition. ${ }^{8}$ Though twin-birth and overcrowding were also significantly associated with under-nutrition $(\mathrm{p}<0.05)$, the odds ratio (OR) included the value 1 . Children who had suffered more than 3 episodes of ARI in the last 1 year had higher prevalence of under-nutrition which was statistically significant. Similar findings were observed in a study by Ramesh et al and Chhabra et al. ${ }^{9,10}$ Use of kerosene as the major source of cooking fuel which is a known risk factor for ARI was also found to be significantly associated with the prevalence of undernutrition.

\section{CONCLUSION}

The high prevalence of under-nutrition could be due to low birth weight, spacing of pregnancy less than 18 months, non -exclusive breast feeding, delayed weaning, recurrent respiratory infections and poor housing conditions. Better maternal care, exclusive breastfeeding, proper weaning and improvement in standard of living in rural area will reduce the problem of under nutrition among children less than 5 years.

Funding: No funding sources Conflict of interest: None declared

Ethical approval: The study was approved by the Institutional Ethics Committee

\section{REFERENCES}

1. Sample Registration System (SRS), Registrar General, India. 2014;49(1):1-6.

2. Park K. Nutrition and Health, Park's Textbook of Preventive and Social Medicine, 23rd Edition.

3. Shreyaswi Sathyanath M, Rashmi, Udaya Kiran N. Prevalence and risk factors of under nutrition among under five children in a rural community, Nitte University Journal of Health Science. 2013;3(4):826.

4. Joshi HS, Joshi MC, Singh A, Joshi P, Khan NI. Determinants of Protein Energy Malnutrition (PEM) In 0-6 Years Children in Rural Community Of Bareilly, Indian Journal of Preventive and Social Medicine. 2011;42(2):154-8.

5. Avachat SS, Phalke VD, Phalke DB. Pravara Med Rev. 2009;1(2):20-2.

6. Meriton Stanly A, Samya V. Prevalence of Undernutrition Among Under 5 Children in a Rural Area, Indian Journal of Applied Research. 2015:5(10):207-9.

7. NFHS 3, National Family Health Survey available at www.rchiips.org/NFHS/nfhs3.html. Last assessed on 2015.

8. Rutstein SO. Effects of preceding birth intervals on neonatal, infant and under-five years mortality and nutritional status in developing countries: evidence from the demographic and health surveys, International Journal of Gynaecology and Obstetrics. 2005;89(Suppl1):S7-24.

9. Yellanthoor RB, Kumar V, Shah B. Prevalence of Malnutrition Among Under-Five Year Old Children With Acute Lower Respiratory Tract Infection Hospitalized at Udupi District Hospital, Archive of Pediatric Infectious Diseases. 2013;1(5):203-6.

10. Chhabra P, Garg S, Mittal SK, Chhabra SK. Risk factors for acute respiratory infections in underfives in a rural community, Indian Journal of Maternal Child Health. 1997;8(1):13-7.

Cite this article as: Samya V, Meriton Stanly A. A population based study on under nutrition and certain associated risk factors among children less than five years in a rural area. Int $\mathbf{J}$ Community Med Public Health. 2015;2:384-7. 